\title{
Article
}

\section{Examination of a new mobile intermittent pneumatic compression device in healthy adults}

Chohan, Ambreen, Abram, Simon, Parkes, Amy, Haworth, Lauren and Whitaker, Justine Claire

Available at http://clok.uclan.ac.uk/31011/

Chohan, Ambreen ORCID: 0000-0003-0544-7832, Abram, Simon, Parkes, Amy ORCID: 0000-0002-7323-9368, Haworth, Lauren ORCID: 0000-0002-17186564 and Whitaker, Justine Claire ORCID: 0000-0003-3885-6245 (2020) Examination of a new mobile intermittent pneumatic compression device in healthy adults. Journal of Wound Care, 29 (6). pp. 370-274. ISSN 0969-0700

It is advisable to refer to the publisher's version if you intend to cite from the work. 10.12968/jowc.2020.29.6.370

For more information about UCLan's research in this area go to http://www.uclan.ac.uk/researchgroups/ and search for <name of research Group>.

For information about Research generally at UCLan please go to http://www.uclan.ac.uk/research/

All outputs in CLoK are protected by Intellectual Property Rights law, including Copyright law. Copyright, IPR and Moral Rights for the works on this site are retained by the individual authors and/or other copyright owners. Terms and conditions for use of this material are defined in the policies page.

\section{CLoK}

Central Lancashire online Knowledge www.clok.uclan.ac.uk

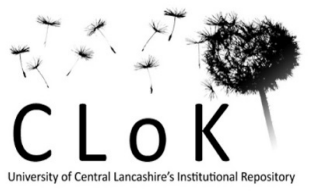




\title{
EXAMINATION OF A NEW MOBILE INTERMITTENT PNEUMATIC COMPRESSION DEVICE IN HEALTHY ADULTS.
}

\author{
Ambreen Chohan, Research Fellow ${ }^{1}$ \\ Simon Abram, Lecturer ${ }^{2}$ \\ Amy Parkes, Lecturer ${ }^{1}$ \\ Lauren Haworth, Senior Research Assistant ${ }^{1}$ \\ Justine C. Whitaker, Senior Lecturer and Nurse Consultant ${ }^{1,2,3}$
}

\footnotetext{
${ }^{1}$ Allied Health Research Unit, University of Central Lancashire, Preston, PR1 2HE

${ }^{2}$ School of Nursing, University of Central Lancashire, Preston, PR1 2HE

${ }^{3}$ Northern Lymphology, Slaidburn, Lancashire, BB7 3AD
}

Corresponding author: Dr Ambreen Chohan, achohan@uclan.ac.uk, +44 1772892793

Allied Health Research Unit, School of Sport and Health Sciences, University of Central Lancashire, Preston, Lancashire, PR1 2HE 